\title{
Happy Home: Happiness at Home as a Lifelong Education Environment
}

\author{
Mustafa Fidan \\ ${ }_{1}^{1}$ Ph.D., Acar Primary School, Turkey, ORCID ID: 0000-0002-2900-7631 \\ Email: gfidanmustafa@gmail.com
}

\begin{abstract}
The COVID-19 pandemic has caused many emergency changes around the world. While schools and workplaces are often closed; homeschooling and working at home increased. Most of the community stayed at home as a result of curfews. With this research, it is aimed to discuss the happy home phenomenon. The mixed method was adopted in the study. A total of 81 participants, consisting of 45 mothers, 24 fathers and 12 students, determined by the maximum variation sampling method constitute the study group. The data obtained using the Oxford Happiness Scale and interview form were analyzed with the SPSS package program and content analysis. According to the quantitative results of the study, the happiness of mothers, fathers and children is at a moderate level. According to the results of qualitative research conducted simultaneously, mothers are happy with family, health, books and kitchen; on the other hand, fathers are happy with family, food and television; children are also happy with playing games, technological tools and toys.
\end{abstract}

Key words: Happiness, home, happy home, lifelong education

\section{Introduction}

Preventive strategies against the COVID-19 pandemic, such as social distance and stay at home have had a great impact on life. The time spent at home has increased. Daily routines of individuals have completely changed. Students, employees or housewives had to live in homes. While restrictions still remain one year has passed. Parents and children had an unusual experience of this new normal. In this context, literature is emerging related to COVID-19.

Many studies have been carried out on students participating in emergency remote teaching at home (Burns \& Gottschalk, 2020; Fidan, 2020; Fidan, 2021a; Keeling \& Haugestad, 2020; Lie et al., 2020; Suryaman et al., 2020; Trout, 2020). These studies yielded results as follows, facilitating children's academic tasks (Suryaman et al., 2020); decrease in social duties (Fidan, 2020); increased student absenteeism (Lie et al., 2020) and students more free (Keeling \& Haugestad, 2020). On the other hand, although restrictions have negative effect students also see the positive aspects of homeschooling (Daniel, 2020). Similarly, with the pandemic, it was understood that education not only contributed to students academically but also physically and emotionally (Burns \& Gottschalk, 2020).

Many studies have been conducted on parents with their increasing roles during the pandemic period (Alqahtani \& Rajkhan, 2020; Bhamani et al., 2020; Brom et al., 2020; Coppola et al., 2020; Fidan, 2021a; Fidan, 2021b; Fidan, 2021c; Garbe et al., 2020 GassmanPines. et al., 2020; Patrick et al., 2020; Susilowati and Azzasyofia, 2020). Former normally, students whose flesh and bones were delivered to the school; new normally they are completely at home. Therefore, parents have to manage students for instruction of school curriculum. According to the studies, instructional roles have been added to increasing parenting roles (Brom et al., 2020; Garbe et al., 2020). As parents' focus is on health and safety, parents somehow manage the increasing roles (Coppola et al., 2020; Fidan, 2021b). However, its problems are unmanageable in economic and psychological terms. In other words, the longer the life fits home constraint; parents faced economic and psychological problems (Alqahtani \& Rajkhan, 2020; Gassman-Pines et al., 2020; Patrick et al., 2020).

However, stay at home restrictions offer opportunities for change and transformation for children and parents in many educational and social contexts (Langlois et al., 2020). The results of the study reveal that pandemic restrictions allow extraordinary transformations (Shearer et al., 2020). The emergence of technology as a savior in every field and the rapid transformation; at least, it has been positively stated in 
many studies that it enables the continuation of jobs, life and education (Chick et al., 2020; Fidan, 2020; Fidan, 2021b; Rose, 2020).

In addition to the positive viewpoint starting with the word "at least", there are also studies that offer mostly negative perspectives. These studies have shown that stay at home has effects on individuals' mental health (Brodeur et al., 2020). In some studies, various activities and solutions are recommended to prevent the negative effects of staying at home for a long time (Slater et al., 2020; Suppawittaya et al., 2020). In another similar study (Song \& Gao, 2020), the positive and negative aspects of working from home were determined that there are positive aspects such as a decrease in weekday work fatigue, albeit a little. In a study investigating family happiness in stay at home restrictions, a significant decrease in the happiness of families was found (Möhring et al., 2020).

There are many studies on happy home in the literature. On the other hand, current research often highlights unhappiness. This study differs from existing studies by focusing on the concept of happy home. In the study, the lives of mothers, fathers and children related to the happy home were highlighted. Although it is accepted as a subjective expression, happiness is defined as a concept related to how much an individual loves his / her life (Veenhoven, 2005). Within the framework of this definition, the happy lives experienced by parents and children were questioned. As a result of this questioning, the concept of happy home was wanted to be discussed.

\section{The questions of the research}

In this study, it was aimed to evaluate home life in the context of happiness, based on the views of parents and children. Based on the results of the study, various inferences were made on the concept of happy home.

In this context, answers to the following questions were sought in the study:

How do mothers, fathers and children view their happiness?

What are the reasons mothers being happy about staying at home?

What are the reasons fathers being happy about staying at home?

What are the reasons children being happy about staying at home?

\section{Method}

The purpose of this study is to understand factors affecting the happy home phenomenon using mixed study method. Mixed method research is the use of qualitative and quantitative research methods together with a holistic approach (Creswell, 2014). This study is also in the simultaneous mixed research method in which qualitative and quantitative data are collected at the same time (Creswell, 2012). Results of qualitative and quantitative data collected at the same time are combined and compared. Results of qualitative and quantitative data collected at the same time and analyzed separately (i.e., checked to see if findings complement each other at the end).

\section{Study Group}

The study group was determined by the maximum variation sampling method, which is one of the purposeful sampling types. A total of 81 participants, consisting of 45 mothers, 24 fathers and 12 students, who spent more time at home during the stay-at-home days took part in the study group. In this way, it is aimed to reach the most ideal data about research problems (Creswell, 2012; 2014).

\section{Data Collection and Analysis}

In this study, data were collected using Personal Information Form, Oxford Happiness Scale-Short Form and Interview Form. Before applying the data collection tools, all participants were given written information about the purpose of the study and voluntary participation approval was obtained. Interview form and scale were applied simultaneously. 
In this study, the data were obtained by online data collection method. The online data collection method, which has been increasingly used in recent years, has assumed the role of a savior for researchers who have difficulties due to social distance rules (Lobe et al., 2020).

\section{Oxford Happiness Scale-Short Form}

The quantitative data of the study were collected using the Oxford Happiness Scale-Short Form. OHQ-SF consists of 8 items and one dimension (Doğan \& Çötok, 2011). In the adaptation study of OHQ-SF, the goodness of fit indexes were determined as $(\chi 2 / \mathrm{df}=2.77$, AGFI $=.93, \mathrm{GFI}=.97, \mathrm{CFI}=.95, \mathrm{NFI}=.92, \mathrm{IFI}=$ .95 , RMSEA $=.07)$. While the Cronbach alpha values obtained in the adaptation study were reported as .85 (Doğan \& Çötok, 2011); Cronbach's alpha coefficient of Cronbach's alpha coefficient of ISS-SF was calculated as .79 for the present study. In other words, the scale is reliable for this study.

In this study, SPSS package program was used for the analysis of quantitative data. The skewness and kurtosis coefficients were examined to test the suitability of the data set to multivariate statistics. The suitability of parametric tests in data analysis was determined based on test results (Büyüköztürk et al., 2012).

\section{Semi-Structured Interview Form}

The qualitative data of the study were collected with a semi-structured interview form. In qualitative research, the experiences of the participants can be revealed by using the interview technique (Creswell, 2012). An interview form was used to reveal the happiness of parents and children during quarantine period. There is a question in the interview form as follows: "What makes you happy at home during your stay at home days?"

The qualitative data were analyzed using content analysis (Giorgi, 1997). For the validity and reliability of the research; Internal validity (credibility), external validity (transferability), internal reliability (consistency) and external reliability (verifiable) were carefully checked. Qualitative interviews were conducted on a voluntary basis. The interviews were recorded with permission. Interview records were reviewed with the participants before analysis. The stages (coding, creating themes from the codes, identifying and interpreting the findings) performed by the researcher were controlled by the expert. Themes were corrected as a result of these checks. Thus, it was aimed to increase the reliability of the research.

\section{Findings}

In this study, which focuses on the happiness of parents and children at home period here. First, Oxford Happiness Scale-Short Form was analyzed based on descriptive statistics. Results are included in Table 1.

Table 1. Happiness scale' descriptive statistics results

\begin{tabular}{lll}
\hline Happiness & Mean & Standard Deviation \\
\hline Mother & 3.57 & .41 \\
Father & 3.64 & .55 \\
Child & 3.23 & .92 \\
\hline
\end{tabular}

Based on Table 1 above, the mean of the happiness scale was between 3.23 and 3.64 in all groups. Based on these results, it can be said that all components of the home have an average happiness. Among the components of the home, the relatively highest average was determined in fathers (3.64).

The second question of the study is as follows: " What are the reasons mothers being happy about staying at home?" The data related to this problem were analyzed by content analysis. Results are included in Table 2 . 
Table 2. Mothers' views on happy home

\begin{tabular}{lll}
\hline Themes & Codes & Frequencies \\
\hline Family & My daughter, my son, my wife, & 38 \\
& my family & \\
& My family's health & 24 \\
& Family meals & 21 \\
My family's love and respect & 19 \\
Chat as a family & 18 \\
My family is peaceful & 13 \\
Everything we are together & 6 \\
Things & My books & 21 \\
& My kitchen & 20 \\
& My stuff & 16 \\
& My cleaning supplies & 10 \\
My musical instruments & 5 \\
Activity & Watching TV Listening to Music & 16 \\
& Taking care of pets & 13 \\
& Take care of plants & 11 \\
& To take time for myself & 10 \\
& Read - write & 9 \\
Thinking & 3
\end{tabular}

Based on Table 2 above, according to mothers, happy home is explained in the themes of family, things and activities consisting of 18 codes. Family theme consists of the following codes; my daughter, my son, my wife, my family, my family's health, family meals, my family's love and respect, chat as a family, my family's peaceful and everything we are together. Things theme consists of the following codes: books, kitchen, stuff, cleaning supplies and musical instruments. Activity theme consists of the following codes; watching TV, listening to music, taking care of pets, take care of plants, to take time for myself, read-write and thinking. As a result, mothers most often describe the happy home with codes such as; family members, family health, books and kitchen.

The third question of the study is as follows: " What are the reasons fathers being happy about staying at home?" The data related to this problem were analyzed by content analysis. Results are included in Table 3.

Table 3. Fathers' views on happy home

\begin{tabular}{lll}
\hline Themes & Codes & Frequencies \\
\hline Family & My children, my wife, my family & 19 \\
& Family time & 10 \\
& My wife's meals & 4 \\
Activity & To be greeted at the door & 3 \\
& Eat food & 15 \\
& To watch TV & 13 \\
& To rest & 9 \\
Things & Reading a book & 3 \\
& Playing board games & 2 \\
& TV, phone & 11 \\
& Family dining table, armchair & 8 \\
& Football match & 5 \\
\hline
\end{tabular}

Based on Table 3 above, according to fathers, happy home is explained in the themes of family, activity and things consisting of 12 codes. Family theme consists of the following codes; my children, my wife, my family, family time, my wife's meals and to be greeted at the door. Activity theme consists of the following codes: eat food, to watch TV, to rest, reading a book and playing board games. Things theme consists of the following codes; TV, phone, family dining table, armchair and football match. As a result, fathers most often describe the happy home with codes such as; family members, meals and TV.

The fourth question of the study is as follows: "What are the reasons children being happy about staying at home?" The data related to this problem were analyzed by content analysis. Results are included in Table 4. 
Table 4. Children' views on happy home

\begin{tabular}{lll}
\hline Themes & Codes & Frequencies \\
\hline Activity & Play a game & 9 \\
& Taking care of pets & 4 \\
& Reading books & 4 \\
& Dancing & 3 \\
& To write-draw something & 2 \\
Things & Technological tools (Computer, & 8 \\
& tablet, phone, TV) & 7 \\
& Toys & 3 \\
Family & Online lessons & 5 \\
& Spending time with my family & 4 \\
& Play games with my brother & 2 \\
\hline
\end{tabular}

Based on Table 4 above, according to children, happy home is explained in the themes of activity, things and family consisting of 11 codes. Activity theme consists of the following codes; play a game, taking care of pets, reading books, dancing and to write-draw something. Things theme consists of the following codes; technological tools (computer, tablet, phone, TV), toys and online lessons. Family theme consists of the following codes; spending time with my family, play games with my brother and my mother's foods. As a result, children most often describe the happy home with codes such as; play a game, technological tools and toys.

\section{Results and Discussion}

According to the results of this mixed study investigating the happy home, all components of the home have an average happiness. In other words, the quantitative results showed that the happiness of mothers, fathers and children is at a moderate level. These findings overlap with the literature. For example, in a study (Yıldırım \& Güler, 2021), happiness scores were found to be average; and the low level of happiness was explained by the pandemic. In another study (Giovanis \& Ozdamar, 2020), it was stated that happiness is not high, and the pandemic affects women's happiness more than men. In a similar study, it was reported that the happiness levels of parents and children were negatively affected by the pandemic; and the lowest level of happiness was observed in mothers (Möhring et al., 2021).

The results of this study and the current research findings show that the pandemic has a negative effect on the happiness of the families. For example, in a research, it was determined that the emotional impact of the pandemic negatively affected the mental health and psychological resilience of parents and children. In addition, it was emphasized that families who had health problems before or who lost their job or a relative in the pandemic are more affected (Valero-Moreno et al., 2021). In another study, it was stated that the pandemic process, which negatively affected the physical and psychological health of families, negatively affected happiness (Ohlbrecht \& Jellen, 2021). In another study, the negative effects of the pandemic on happiness were revealed for similar reasons (Guo et al., 2021).

The fact that the average of happiness in these results has a decreasing trend does not mean that there is no happiness. The qualitative results of the research show the reasons for happiness at home. Therefore, the fact that the study was mixed method worked in this context. While the quantitative part of the research shows that happiness rates decrease; the qualitative part revealed the reasons for happiness at home. According to the qualitative interview results conducted simultaneously with the quantitative part of the study, the reasons for happiness at home were determined despite every negativity.

According to qualitative analysis results, happy home is combined in various codes on the themes of family, things and activity. Mothers most often expressed happiness with family members, health, books, and kitchen. İn addition fathers, mostly happy with family members, meals and TV. On the other hand, children stated that they are happy with playing games, technological tools and toys. Existing literatures supports study results. In a recent study examining happiness at home (Waters, 2020), family members, activities and some special resources make family members happy. In another study (Chen et al., 2020), the interactions between parents and children in the playgrounds at home were examined. Accordingly, it has been concluded that games and toys are not only good for children but also for mothers and fathers. According to the research, playing games together increases mutual understanding and provides emotional recovery. In a similar study (Ho et al., 2016), it was found that improving the communication between family members positively, spending time together in the kitchen and spending time together had positive contributions to happiness. 
When the qualitative results of this research are evaluated together with what an unchangeable component of the happy home has emerged. Family. The family theme is a common component that makes parents and children happy. Therefore, the value of the family phenomenon can be expressed as the most important result of the current happy home research. In the literature, happy home researches are generally named as happy family. In one of these studies (Cummins, 2018), the happy family consists of three fundamentals: family income, intra-family relationships and life satisfaction. In other words, the family factor protects happiness against the negative economic effects of the pandemic and the decrease in life satisfaction.

There are studies in the literature that support the family's protectiveness in the context of the happy home. It has been stated in a study that family unity, solidarity, communication, and appreciation reveal a happy family (Lee et al., 2005). According to Hermann's (2010) research, happy family depends on family members who can combine the concepts of me and you in the concept of us with love, respect and trust.

\section{Conclusions and Recommendations}

In this study, happy home was investigated with a mixed method. Happiness, which was determined to be at a moderate level in the quantitative part of the study, was examined in depth in the qualitative part of the study. As a result of the analysis, the happiness of mothers, fathers and children were discussed with the goal of happy home phenomenon. According to the study results, the most important component of a happy home is family. In addition, various activities were determined as other components of the happy home phenomenon. Based on these results, the following recommendations are given.

Happy home consists of happy mothers, happy fathers and happy children. The finding that all individuals at home contribute to each other's happiness is important. It may be suggested that individuals support each other in order to increase happiness at home. Because one's happiness indirectly affects the other. In addition, happy family is both the source and the result of the happiness of parents and children.

On the other hand, games and toys, which have the highest proportion in children's happiness, can contribute to the total happiness of the family. Family time spent with games and toys can support the happy home phenomenon. Also the happiness of mothers can be supported. Because in this research, the happiness of mothers was more affected by the pandemic. Furthermore, it can be recommended that all individuals in the home respect each other's reasons for happiness.

In addition, this study is limited to a small study group during the pandemic period. New studies can be conducted in different samples and after the effects of the pandemic are reduced. In addition to, this research is limited to online data collection method. After the social distance rules are over, studies can be done with face-to-face data collection methods.

\section{References}

Alqahtani, A. Y., \& Rajkhan, A. A. (2020). E-learning critical success factors during the COVID-19 pandemic: A comprehensive analysis of e-learning managerial perspectives. Education Sciences, 10(9), 216-231.

Bhamani, S., Makhdoom, A. Z., Bharuchi, V., Ali, N., Kaleem, S., \& Ahmed, D. (2020). Home learning in times of COVID: Experiences of parents. Journal of Education and Educational Development, 7(1), 9-26.

Brodeur, A., Clark, A. E., Fleche, S., \& Powdthavee, N. (2021). COVID-19, lockdowns and well-being: Evidence from Google Trends. Journal of public economics, 193, 1-56.

Brom, C., Lukavský, J., Greger, D., Hannemann, T., Straková, J., \& Švaříček, R. (2020). Mandatory Home Education During the COVID-19 Lockdown in the Czech Republic: A Rapid Survey of 1st-9th Graders' Parents. Frontiers in Education (Vol. 5, p. 103). Frontiers.

Burns, T. and F. Gottschalk (eds.) (2020), Education in the Digital Age: Healthy and Happy Children, Educational Research and Innovation, OECD Publishing, Paris, https://doi.org/10.1787/1209166aen.

Büyüköztürk, Ș., Çokluk, Ö., \& Köklü, N. (2012). Sosyal bilimler için istatistik (11. Baskı). Ankara: Pegem Akademi.

Chen, C., Yuan, Z., \& Zhu, H. (2020). Playing, parenting and family leisure in parks: exploring emotional geographies of families in Guangzhou Children's Park, China. Children's Geographies, 18(4), 463-476.

Chick, R. C., Clifton, G. T., Peace, K. M., Propper, B. W., Hale, D. F., Alseidi, A. A., \& Vreeland, T. J. (2020). Using technology to maintain the education of residents during the COVID-19 pandemic. Journal of surgical education, 77(4), 729-732.

Coppola, M., Immacolata, S., \& Masullo, G. (2020). Parents in Pandemic: parents' perceptions of risks and psychological, relational, and pedagogical needs in childhood during the COVID-19 emergency in Italy. http://dspace.epoka.edu.al/handle/1/1881 
Creswell, J. W. (2012). Educational research : planning, conducting, and evaluating quantitative and qualitative research (4. Baskı). USA: Pearson Education Inc.

Creswell, J. W. (2014). Research design: Qualitative, quantitative, and mixed methods approaches (4. Baskı). Thousand Oaks, CA: Sage.

Cummins, R. A. (2018). The golden triangle of happiness: Essential resources for a happy family. International Journal of Child, Youth and Family Studies, 9(4), 12-39.

Daniel, S. J. (2020). Education and the COVID-19 pandemic. Prospects, 49, 91-96.

Doğan, T., \& Çötok, N. A. (2011). Oxford mutluluk ölçeği kısa formunun Türkçe uyarlaması: Geçerlik ve güvenirlik çalışması. Turkish Psychological Counseling and Guidance Journal, 4(36). 165-172

Fidan, M. (2020). Covid-19 belirsizliğinde eğitim: İlkokulda zorunlu uzaktan eğitime ilişkin öğretmen görüşleri. Uşak Üniversitesi Eğitim Araştırmaları Dergisi, 6(2), 24-43.

Fidan, M. (2021a), COVID-19 and primary school 1st grade in turkey: starting primary school in the pandemic based on teachers' views. Journal of Primary Education, 3(1), 15-24. https://doi.org/10.52105/temelegitim.3.1.2

Fidan, M. (2021b). Remote Teaching's managerial innovation in the pandemic: Plasma metaphor for online classrooms. International Journal of Leadership Training (IJOLT), 1(1), 1-9.

Fidan, M. (2021c). Happy online school. Açıköğretim Uygulamaları ve Araştırmaları Dergisi (AUAd), 7(2), 149171. https://doi.org/10.51948/auad.863191

Garbe, A., Ogurlu, U., Logan, N., \& Cook, P. (2020). Parents' experiences with remote education during covid19 school closures. American Journal of Qualitative Research, 4(3), 45-65.

Gassman-Pines, A., Ananat, E. O., \& Fitz-Henley, J. (2020). COVID-19 and parent-child psychological wellbeing. Pediatrics, 146(4).1-11.

Giorgi, A. (1997). The theory, practice, and evaluation of the phenomenological method as a qualitative research procedure. Journal of phenomenological psychology, 28(2), 235-260.

Giovanis, E., \& Ozdamar, O. (2020). Who is Left Behind? Altruism of Giving, Happiness and Mental Health during the COVID-19 Period in the UK. Applied research in quality of life, 1-26. https://doi.org/10.1007/s11482-020-09900-8

Guo, J., De Carli, P., Lodder, P., Bakermans-Kranenburg, M. J., \& Riem, M. (2021). Maternal mental health during the COVID-19 lockdown in China, Italy, and the Netherlands: a cross-validation study. Psychological medicine, 1-11. Advance online publication. https://doi.org/10.1017/S0033291720005504

Hermann, D. (2010). One happy family. In F. du Toit \& E. Doxtader (Eds.), In the balance: South Africans debate reconciliation (pp. 118-124). Auckland Park: Jacana.

Ho, H. C., Mui, M., Wan, A., Ng, Y. L., Stewart, S. M., Yew, C., ... \& Chan, S. S. (2016). Happy Family Kitchen: A community-based research for enhancing family communication and well-being in Hong Kong. Journal of Family Psychology, 30(6), 752.

Keeling, C., \& Haugestad, A. (2020). Digital Student Preferences: a study of blended learning in Norwegian higher education. Nordic Journal of Modern Language Methodology, 8(2), 89-112.

Langlois, S., Xyrichis, A., Daulton, B. J., Gilbert, J., Lackie, K., Lising, D., ... \& Khalili, H. (2020). The CoVID-19 crisis silver lining: interprofessional education to guide future innovation. Journal of interprofessional care, 34(5), 587-592.

Lee, Y. H., Chi, Y. S., \& Choi, B. A. (2005). Guidelines for Happiness: Lessons from the Cases in the'Happy Family Story Contest'. Journal of Korean Home Management Association, 23(1), 41-51.

Lie, A., Tamah, S. M., Gozali, I., Triwidayati, K. R., Utami, T. S. D., \& Jemadi, F. (2020). Secondary school language teachers' online learning engagement during the COVID-19 pandemic in Indonesia. Journal of Information Technology Education: Research, 19, 803-832.

Lobe, B., Morgan, D., \& Hoffman, K. A. (2020). Qualitative data collection in an era of social distancing. International Journal of Qualitative Methods, 19, https://doi.org/10.1177/1609406920937875

Möhring, k., Naumann, E., Reifenscheid, M., Wenz, A., Rettig, T., Krieger, U., Friedel, S., Finkel, M., Cornesse, C., \& Blom, A. G. (2021). The COVID-19 pandemic and subjective well-being: longitudinal evidence on satisfaction with work and family, European Societies, 23(1), 601-617, https://doi.org/10.1080/14616696.2020.1833066

Ohlbrecht, H., \& Jellen, J. (2021): Unequal tensions: the effects of the coronavirus pandemic in light of subjective health and social inequality dimensions in Germany, European Societies, DOI: $10.1080 / 14616696.2020 .1852440$

Patrick, S. W., Henkhaus, L. E., Zickafoose, J. S., Lovell, K., Halvorson, A., Loch, S., ... \& Davis, M. M. (2020). Well-being of parents and children during the COVID-19 pandemic: a national survey. Pediatrics, 146(4). https://doi.org/10.1542/peds.2020-016824 
Rose S. (2020). Medical student education in the time of COVID19. JAMA. 323(21), 2131-2132.

Valero-Moreno, L. Lacomba-Trejo, A. Tamarit, et al., (2021). Psycho-emotional adjustment in parents of adolescents: A cross-sectional and longitudinal analysis o..., Journal of Pediatric Nursing, https://doi.org/10.1016/i.pedn.2021.01.028

Shearer, R. L., Aldemir, T., Hitchcock, J., Resig, J., Driver, J., \& Kohler, M. (2020). What students want: A vision of a future online learning experience grounded in distance education theory. American Journal of Distance Education, 34(1), 36-52.

Slater, S. J., Christiana, R. W., \& Gustat, J. (2020). Recommendations for Keeping Parks and Green Space Accessible for Mental and Physical Health During COVID-19 and Other Pandemics. Preventing chronic disease, 17, E59. https://doi.org/10.5888/pcd17.200204

Song, Y., \& Gao, J. (2020). Does telework stress employees out? A study on working at home and subjective well-being for wage/salary workers. Journal of Happiness Studies, 21(7), 2649-2668.

Suppawittaya, P., Yiemphat, P., \& Yasri, P. (2020). Effects of social distancing, self-quarantine and selfisolation during the COVID-19 pandemic on people's well-being, and how to cope with it. International Journal of science and healthcare research, 5(2), 12-20.

Suryaman, M., Cahyono, Y., Muliansyah, D., Bustani, O., Suryani, P., Fahlevi, M., ... \& Munthe, A. P. (2020). COVID-19 pandemic and home online learning system: Does it affect the quality of pharmacy school learning?. Systematic Reviews in Pharmacy, 11(8), 524-530.

Susilowati, E. \& Azzasyofia, M. (2020). The parents stress level in facing children study from home in the early of COVID-19 pandemic in Indonesia. International Journal of Science and Society, 2(3), 1-12.

Veenhoven, R. (2005). Is life getting better? How long and happily do people live in modern society? European psychologist, 10(4), 330-343.

Waters, L. (2020). Using positive psychology interventions to strengthen family happiness: a family systems approach. The Journal of Positive Psychology, 15(5), 645-652.

Yıldırım, M., \& Güler, A. (2021). Positivity explains how COVID-19 perceived risk increases death distress and reduces happiness. Personality and individual differences, 168, 110347. https://doi.org/10.1016/j.paid.2020.110347 